\title{
Pembungkaman Perempuan Pekerja Seni Korban Kekerasan Seksual di Media Sosial Studi Muted Group Theory pada Unggahan Instagram Stories Penyanyi Dangdut Via Vallen (@ viavallen)
}

\author{
Nicky Stephani ${ }^{1}$, Billy K. Sarwono ${ }^{2}$ \\ ${ }^{1}$ Department of Communication Science, Universias Pembangunan Jaya \\ South Tangerang, Banten 15413, Indonesia \\ nicky.stephani@upj.ac.id \\ ${ }^{2}$ Departemen Ilmu Komunikasi, Universitas Indonesia \\ Depok, Jawa Barat, 16424, Indonesia \\ billy.sarwono@ui.ac.id
}

Received 26 May 2020, Revised 16 October 2020, Accepted 2 November 2020

\begin{abstract}
This study aims to describe the muting of female art worker who was a victim of sexual violence in social media. In addition, this study also aims to identify the cause of her muteness. The conceptual framework of this research is derived from muted group theory, previous studies about art worker, definitions and types of sexual violence, women in patriarchal culture, sexual violence and patriarchal culture, Instagram, women and social media. This study uses critical constructionism paradigm and descriptive qualitative research type. The analytical units in this study are two Instagram stories which were posted by a famous dangdut singer Via Vallen and exposed her sexual harassment experience to the public. Roland Barthes' semiotics analysis is used in this study to explain denotative and connotative meanings also revealed the myths behind the displayed symbols. The results of this study indicates that although female art worker has access to social media, where she can express their resistance towards sexual harassment in front of millions of her followers, at the end she remains muted. Muting occures when female art worker can not articulate her experience of sexual violence in front of the dominant group. This is caused by patriarchal ideology which roots in our society and operates systematically to mute the expression of female art worker who was a victim of sexual violence on social media. Systematic patriarchal operations are carried out by constructing the position of female art worker in society, fostering stigma and stereotypes about them in our daily life, naturalizing many forms of sexual violence that afflicted them, and ignoring their expression about sexual violence.
\end{abstract}

Keywords: muting, female art worker, sexual harassment, Instagram, patriarchy

\begin{abstract}
Abstrak - Penelitian ini bertujuan untuk mendeskripsikan pembungkaman terhadap perempuan pekerja seni yang menjadi korban kekerasan seksual di media sosial. Selain itu, penelitian ini juga bertujuan untuk mengidentifikasi penyebab terjadinya pembungkaman dari perspektif muted group theory. Penelitian ini menggunakan paradigma konstruksionisme kritis dan jenis penelitian kualitatif deskriptif. Unit analisis dalam penelitian ini adalah dua unggahan Instagram stories penyanyi dangdut Via Vallen tentang peristiwa pelecehan seksual yang ia alami. Metode analisis yang digunakan adalah semiotika Roland Barthes yang menjabarkan makna denotatif dan konotatif serta mengungkap mitos di balik simbol-simbol yang ditampilkan. Hasil penelitian ini menunjukkan bahwa meskipun perempuan pekerja seni memiliki akses ke media sosial, di mana ia dapat dengan bebas menyatakan perlawanannya terhadap pelecehan seksual di hadapan jutaan pengikutnya, pada akhirnya ia tetap terbungkam. Pembungkaman terjadi ketika perempuan pekerja seni tidak dapat mengartikulasikan pengalaman pelecehan seksual di hadapan anggota kelompok dominan. Hal ini disebabkan oleh ideologi patriarki yang mengakar di masyarakat dan beroperasi secara sistematis di media sosial untuk membungkam ekspresi perempuan pekerja seni yang menjadi korban pelecehan seksual. Operasi patriarki yang tersistem dilakukan dengan mengkonstruksi posisi perempuan pekerja seni dalam masyarakat, menyuburkan stigma dan stereotip tentang perempuan pekerja seni di lingkungan sosial, mewajarkan bentuk-bentuk kekerasan seksual yang menimpa perempuan pekerja seni, dan mengabaikan aspirasi perempuan pekerja seni tentang pelecehan seksual.

Kata Kunci: pembungkaman, perempuan pekerja seni, pelecehan seksual, Instagram, patriarki
\end{abstract}




\section{PENDAHULUAN}

Pada 4 Juni 2018, penyanyi dangdut Via Vallen melalui akun resminya @viavallen mengunggah gambar berisikan potongan pesan bernada mesum yang ditujukan kepadanya dari pengirim pesan yang merupakan seorang laki-laki. Dalam pesannya, lakilaki tersebut menginginkan Via Vallen masuk ke kamarnya dengan mengenakan pakaian seksi. Tidak terima dengan isi pesan tersebut, Via Vallen meluapkan emosinya dengan mengunggah pesan mesum tersebut dan menyampaikan sikap keberatannya terhadap perlakuan laki-laki tersebut. Tidak lama berselang, Via Vallen kembali mengunggah gambar halaman percakapan (chat) dengan pelaku yang nampak keberatan karena pesannya diunggah di Instagram stories. Unggahan stories Via Vallen mengundang beragam respon warganet.

Via Vallen adalah satu dari sedikit korban pelecehan seksual yang dengan berani menceritakan pengalamannya kepada orang lain, tidak hanya bercerita pada satu dua orang tetapi kepada publik yang menjadi pengikutnya (followers) di Instagram. Ada warganet mengapresiasi pernyataan sikap Via Vallen tetapi tidak sedikit pula komentar yang menyudutkan dirinya. Kebanyakan komentar bersentimen negatif mengaitkan kasus pelecehan seksual yang dialami Via Vallen dengan resiko profesinya sebagai pekerja di industri seni dan hiburan.

Catatan Tahunan Komisi Nasional Anti Kekerasan terhadap Perempuan (Komnas Perempuan) mengungkapkan bahwa kekerasan terhadap perempuan di Indonesia meningkat sebesar 25 persen pada tahun 2017. Terdapat 348.446 kasus kekerasan terhadap perempuan yang dilaporkan dan ditangani selama tahun 2017. Kekerasan di ranah privat atau personal adalah yang paling tinggi yaitu sebesar 72,2 persen, diikuti dengan kekerasan di ranah publik atau komunitas sebesar 26 persen dan ranah negara sebesar 1,8 persen. Tiga jenis kekerasan seksual yang paling banyak terjadi di ranah komunitas adalah pencabulan, pelecehan seksual, dan perkosaan (Komnas Perempuan, 2018).

Kekerasan seksual juga menjadi fenomena krusial di berbagai negara. Data yang dipublikasikan oleh World Health Organization (WHO) menunjukkan bahwa satu dari tiga perempuan di dunia mengalami kekerasan seksual dan atau fisik yang dilakukan oleh pasangannya atau pihak lain (World Health Organization, 2017). Secara lebih spesifik, berdasarkan hasil survei tentang kekerasan seksual dari berbagai negara, diperkirakan bahwa tidak kurang dari 75 persen atau 2,7 miliar perempuan di dunia yang berusia minimal 18 tahun pernah mengalami pelecehan seksual (Inter Press Service, 2018). Survei online yang dilakukan lembaga nonprofit Stop Street Harassment menunjukkan bahwa 81 persen perempuan pernah pengalami pelecehan seksual selama hidupnya yang meliputi pelecehan verbal melalui siulan atau komentar bernuansa seksual yang tidak diinginkan, pelecehan fisik, hingga pelecehan di ranah siber (Chatterjee, 2018).

Selama ini pelecehan seksual merupakan isu yang sunyi, ia terkunci bersama bungkamnya korban (Gash \& Harding, 2018). Media digital sebagai ruang publik sebenarnya membuka kesempatan bagi siapapun yang ingin berekspresi, termasuk perempuan korban pelecehan seksual yang selama ini bungkam. Namun sayangnya, berkaca dari kasus Via Vallen, perempuan yang mengekspresikan peristiwa pelecehan seksual justru harus berhadapan dengan upaya-upaya kelompok dominan yang berusaha meredamnya. Upaya pembungkaman dilakukan untuk meredam ekspresi perempuan yang melawan struktur kelompok dominan dan mengembalikan perempuan pada peran dan tempatnya. Mitos peran gender dalam struktur tersebut membuat masyarakat meyakini bahwa perempuan adalah makhluk yang lemah sehingga ia sebaiknya diam dan menerima apa yang menimpanya tanpa perlawanan.

Profesi korban yang merupakan seorang penyanyi dangdut membuat persoalan ini menjadi sengkarut. Meskipun termasuk dalam kategori pekerja seni profesional, pandangan masyarakat terhadap penyanyi dangdut dengan aktris, pemain teater atau seniman lain tidaklah sama. Bahkan dalam kategori sesama penyanyi pun, dangdut dianggap sebagai musik kelas bawah dan penyanyi dangdut perempuan kerap dipandang sebelah mata.

Dalam kehidupan sehari-hari, penyanyi dangdut perempuan berekspresi dalam kungkungan mitos seksualitas dan feminitas yang dilanggengkan struktur patriarki. Sosok penyanyi dangdut perempuan dipandang sebagai simbol sensualitas yang menggoda. Pemberitaan media yang mengulik kehidupan pribadi penyanyi dangdut perempuan turut membentuk citra dan stereotip yang dilekatkan kepada mereka. Stereotip kebertubuhan tersebut memicu pengategorian feminitas penyanyi dangdut ke dalam kelompok yang 'tidak baik' atau istilahnya 'bukan perempuan baik-baik.'

Kasus ini menunjukkan bahwa selantang apapun korban bersuara, ia tetap dipandang dari status dan perannya. Ketika masyarakat menyadari bahwa korban adalah seorang penyanyi dangdut maka kemudian upaya yang muncul adalah komentarkomentar yang meragukan keterangannya. Dengan cara itulah kelompok dominan meredam suara korban.

Berdasarkan permasalahan tersebut, penelitian ini berusaha untuk menjawab pertanyaan tentang (1) Bagaimana pembungkaman terhadap penyanyi dangdut perempuan korban pelecehan seksual terjadi di Instagram dan (2) Mengapa pembungkaman terhadap penyanyi dangdut perempuan korban pelecehan seksual dapat terjadi di Instagram. Penelitian ini bertujuan untuk mendeskripsikan praktik dan mengidentifikasi penyebab terjadinya pembungkaman terhadap penyanyi dangdut 
perempuan korban pelecehan seksual di media sosial Instagram.

Dalam menganalisis data, peneliti menggunakan perspektif muted group theory dan semiotika Roland Barthes. Muted group theory berasumsi bahwa sistem bahasa kelompok dominan dibangun dari pengalaman dan perspektif laki-laki sehingga perempuan tidak dapat mengemukakan apa yang ingin dikatakan pada tempat dan waktu yang mereka inginkan. Dalam narasi pelecehan seksual, sistem bahasa dominan mengabaikan suara dan mendevaluasi pemikiran korban sehingga korban pada akhirnya memilih untuk diam.

Untuk mengetahui bagaimana mekanisme pembungkaman yang menimpa korban, peneliti menganalisisnya dari kerangka semiotika. Semiotika Roland Barthes membedah teks media menjadi simbol visual dan tekstual yang kemudian dianalisis berdasarkan yang dilihat (denotatif), yang dimaknai (konotatif), dan wacana yang menaungi makna (mitos). Melalui ketiga aspek ini, peneliti dapat membongkar ideologi yang beroperasi dibalik teks dan peristiwa pembungkaman korban.

\section{METODE PENELITIAN}

Penelitian ini menggunakan pendekatan kualitatif dengan paradigma critical constructionism yang merupakan sintesis dari dua teori yaitu teori konflik dan interaksi simbolik. Paradigma critical constructionism memandang peristiwa pelecehan seksual yang dialami penyanyi dangdut perempuan sebagai realitas sosial yang dimaknai secara berbeda karena adanya perbedaan pengalaman dan konstruksi sosial yang sarat dengan relasi kuasa. Penelitian ini berusaha menganalisis makna dari simbol-simbol yang terdapat dalam unggahan Instagram stories penyanyi dangdut Via Vallen tentang peristiwa pelecehan seksual yang ia alami. Kemudian, peneliti akan membongkar ideologi yang ada di balik unggahan tersebut secara kritis.

Peneliti menggunakan metode analisis semiotika Roland Barthes dengan fokus analisis pada penuntunan dan pertukaran makna dalam teks. Melalui metode semiotika, tanda atau simbol dalam unggahan Instagram stories penyanyi dangdut Via Vallen tentang peristiwa pelecehan seksual yang ia alami dapat diinterpretasikan lebih dalam sehingga makna yang terbentuk dari tanda-tanda tersebut dapat teridentifikasi. Analisis semiotika Roland Barthes dipilih karena metode tersebut menawarkan pendekatan untuk menganalisis apa yang ada di balik makna tersebut, yaitu mitos. Peneliti mengidentifikasi adanya mitos patriarki yang mempengaruhi produksi makna melalui bahasa yang dipertukarkan antara Via Vallen dan laki-laki pengirim pesan dalam unggahan Instagram stories.

Unit analisis dalam penelitian ini adalah dua unggahan Instagram stories akun penyanyi dangdut Via Vallen (@viavallen) tentang peristiwa pelecehan seksual yang ia alami. Keduanya diunggah pada tanggal 4 Juni 2018. Berikut adalah tampilan kedua unggahan Instagram stories tersebut:
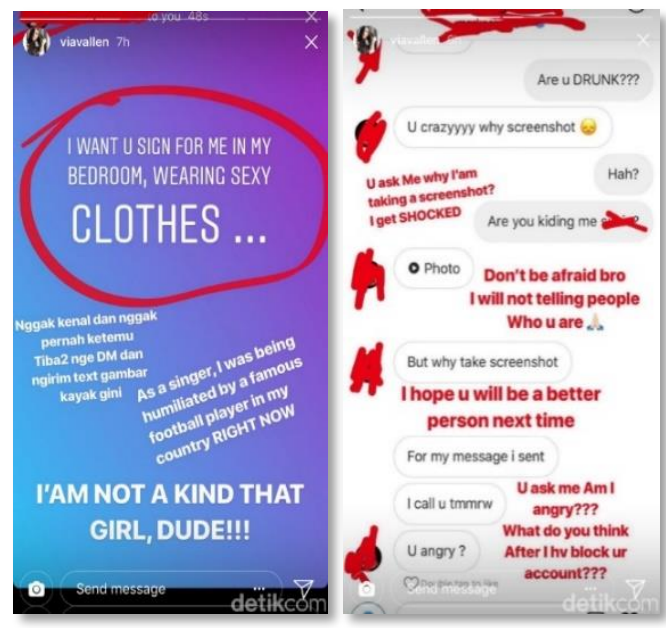

Gambar 1. Unggahan Instagram stories 1 (kiri) dan 2 (kanan) (Detik, 2018)

\section{TEMUAN DAN ANALISIS}

Berdasarkan pengamatan terhadap simbol verbal (kata, kalimat) dan non-verbal (warna, grafis) dalam unggahan Instagram stories penyanyi dangdut Via Vallen, terdapat perbedaan makna pesan "I want $u$ sign for me in my bedroom, wearing sexy clothes" bagi Via Vallen dan pengirim pesan. Perbedaan pemaknaan ini berujung pada perbedaan cara menyikapi pesan tersebut. Perbedaan makna dan sikap terhadap pesan tersebut tergambar jelas dalam dua unggahan Instagram stories penyanyi dangdut Via Vallen.

Selaku penerima pesan, Via Vallen memaknai pesan tersebut sebagai pesan mesum karena simbolsimbol seksualitas dan keintiman yang melekat pada kata "bedroom" dan "sexy clothes". Absennya konteks situasi dan relasi yang melatarbelakangi pengiriman pesan tersebut menguatkan persepsi Via Vallen bahwa pesan tersebut merupakan pelecehan seksual terhadap dirinya sebagai penyanyi dangdut perempuan. Ia merasa telah dihina atau direndahkan oleh si pengirim pesan. Oleh karenanya, ia marah dan meluapkan emosinya melalui kalimat-kalimat tanggapan dalam unggahan Instagram stories-nya.

Sedangkan bagi pengirim pesan, isi pesan tersebut bukanlah apa-apa. Ia tidak memaknai pesan tersebut sebagai pesan yang bersifat mesum atau menggoda, ia merasa tidak ada yang salah dengan pesan tersebut. Oleh karena itu, pengirim pesan tidak menganggap dirinya telah melakukan pelecehan seksual terhadap penyanyi dangdut Via Vallen. Bagi si pengirim pesan, masalah muncul ketika pesan tersebut dibuka dan disebarkan ke publik melalui unggahan Instagram stories Via Vallen. Ia memaknai apa yang dilakukan oleh Via Vallen sebagai tindakan yang gila dan tidak beralasan.

Singkatnya, Via Vallen merasa pesan tersebut merupakan tindak pelecehan seksual terhadap dirinya, sedangkan pengirim pesan yang merupakan seorang 
laki-laki tidak merasa demikian. Pemaknaan pesan yang berbeda antara Via Vallen sebagai penerima pesan dan laki-laki tersebut sebagai pengirim pesan bukan lah sebuah kebetulan psikologis semata. Terdapat mitos-mitos tentang perempuan yang dikonstruksi oleh masyarakat patriarki dan melatarbelakangi lahirnya pemaknaan yang berbeda terhadap pesan dan simbol-simbol yang ada di dalamnya. Mitos-mitos tersebut merasuk ke dalam praktik sosial masyarakat sehingga kehadirannya tidak disadari oleh individu laki-laki maupun perempuan.

Mitos dianggap sebagai naturalisasi budaya melalui penanaman nilai-nilai dominan, sikap, keyakinan, dan struktur sosial sebagai norma (Chandler, 2006). Mereka berfungsi untuk menjabarkan dasar-dasar masyarakat, peran individu, dan hubungan antar individu dalam masyarakat. Oleh karena itu, mitos memainkan peranan kunci dalam representasi dan peran perempuan dalam budaya kontemporer. Operasi mitos dalam kehidupan sosial tidak mencolok, bahkan cenderung tidak disadari, tetapi jika dicermati lebih lanjut dampaknya terhadap kehidupan perempuan sangat terasa. Terdapat tiga mitos utama dalam unggahan Instagram stories Via Vallen yaitu mitos peran gender, mitos tubuh perempuan, dan mitos feminitas.

\section{Mitos Peran Gender: Perempuan Kelas Dua}

Setiap masyarakat diatur oleh sistem seksual yang disebut gender. Chodorow (2012) mendefinisikan gender sebagai " a set of arrangements by which the biological raw material of human sex and production is shaped by human soscial intervention and satisfied in a conventional manner". Jadi, pengaturan masyarakat ini dilakukan atas konstruksi masyarakat dan bukan sesuatu yang alamiah. Perempuan dan lakilaki selalu diberi peran dalam masyarakat. Dapat dikatakan bahwa masyarakat dibentuk dan dipelihara melalui peran berbeda yang dilakukan oleh laki-laki dan perempuan. Perbedaan peran tersebut lah yang menentukan dasar-dasar pola sosial. Dalam praktiknya, laki-laki dan perempuan tidak memiliki hak istimewa yang sama ketika berhubungan dengan peran.

Dalam kebanyakan masyarakat, laki-laki memiliki peran yang dominan sementara perempuan tunduk kepada laki-laki. Pola sosial ini lahir dari patriarki yang mengacu pada sistem dominasi lakilaki dan berbagai praktik sosial yang memperkuat keberadaannya (Milestone, 2012). Dominasi peran laki-laki ini implikasinya besar bagi perempuan sebab ia melahirkan subordinasi perempuan dalam hal politik, budaya, reproduksi, dan ekonomi (Arivia, 2006). Di bidang politik misalnya, politik selalu menjadi ruang yang diperuntukkan bagi laki-laki dan oleh karenanya mereka berusaha untuk mempertahankannya dengan menanamkan dan menyuburkan ideologi patriarki. Dalam hal ini, media memainkan peran kunci dalam merepresentasikan dan menggambarkan perempuan dan peran mereka melalui film, acara televisi, buku, musik, dan sebagainya (vanZoonen, 2000).

Barthes (2007) dalam bukunya yang berjudul Mythology mengungkapkan bahwa perempuan selalu diberi peran dalam masyarakat sebagai "produsen" dan pengurus anak serta rumah tangga. Apapun upaya pembaruan yang dilakukan oleh perempuan, misal perempuan-perempuan kreatif yang berkarya di luar rumah, akan selalu dikaitkan dengan peran gendernya di ranah domestik. Inilah yang disebut Barthes sebagai mitos pembaruan dan anak (novelty and children) dalam kehidupan perempuan. Dalam masyarakat di mana patriarki menghegemoni, peran perempuan seperti ini membuat mereka tunduk di bawah dominasi laki-laki yang selalu berusaha memposisikan perempuan pada tempat yang seharusnya (Chodorow, 2012).

Walby (2013) menyoroti perubahan relasi gender selama satu abad terakhir dan kaitannya dengan patriarki. Beberapa contoh perubahan relasi gender yang dimaksud seperti semakin banyaknya perempuan yang bekerja di bidang yang sama dengan laki-laki, semakin berkurangnya selisih upah antara laki-laki dan perempuan serta semakin tertutupnya jurang kualifikasi pendidikan laki-laki dan perempuan. Kondisi ini seolah-olah menunjukkan bahwa patriarki yang selama ini membelenggu perempuan sudah tidak ada lagi atau kalaupun masih ada maka kadar patriarki tidak lagi sama seperti sebelumnya. Namun, apakah benar demikian? Walby (2013) berargumen bahwa bukan hanya terjadi perubahan pada kadar patriarki, melainkan juga pada bentuknya, yaitu pergeseran dari patriarki bentuk privat ke bentuk publik.

Dalam patriarki privat, produksi rumah tangga menjadi arena utama penindasan perempuan. Pekerjaan perempuan dirampas oleh individu patriarki di dalam keluarga sehingga mengakibatkan penyingkiran atau marjinalisasi kaum perempuan. Sedangkan dalam patriarki publik, perempuan tidak secara langsung dikecualikan dari ruang publik. Sama halnya dengan laki-laki, mereka memiliki akses formal ke lembaga-lembaga penting seperti pasar tenaga kerja, politik, atau pendidikan. Secara hukum, perempuan tidak dilarang untuk melakukan hal-hal tersebut di ruang publik. Sebagai gantinya, patriarki mengendalikan perempuan di ruang publik secara tidak langsung dan kolektif sehingga mengakibatkan segregasi dan subordinasi kaum perempuan di ruang publik. Kondisi ini disebut Milestone dan Meyer (2012) sebagai kesetaraan formal.

Pada akhirnya, dimanapun perempuan berada dan apapun yang mereka lakukan, mereka tetap menjadi warga kelas dua, submisif, dan inferior terhadap kekuasaan laki-laki. Berdasarkan mitos tersebut, terciptalah cara-cara untuk mengontrol perempuan seperti produksi rumah tangga, organisasi kerja (upah), negara, kekerasan laki-laki, heteroseksualitas, dan institusi budaya (Walby, 2013). 
Dalam perspektif patriarki, opresi terhadap perempuan, apapun bentuknya, adalah hal yang lumrah dilakukan untuk menjaga tatanan sosial yang mengagungkan dominasi laki-laki. Dengan memposisikan perempuan sebagai warga kelas dua, praktik-praktik subordinasi dan marjinalisasi menjadi tidak dapat dihindari.

Peran gender, seperti dikotomi laki-laki superior dan perempuan inferior, tidak terjadi secara alamiah. Ia merupakan konstruksi sosial dalam masyarakat kelas yang menurunkan derajat perempuan dan membuat posisi laki-laki menjadi lebih tinggi. Lakilaki memenangkan supremasi sosial dalam melawan dan menaklukan perempuan dan ketidaksanggupan perempuan adalah produk dari sistem sosial yang telah menghasilkan dan memupuk ketidaksetaraan, inferioritas, diskriminasi dan degradasi lainnya. Sayangnya, fakta ini tersembunyi di balik mitos bahwa perempuan secara alamiah adalah manusia yang lebih rendah.

Kerjasama patriarki dan sistem kelas membentuk opresi berlapis bagi kaum perempuan karena keduanya tidak hanya ada di 'permukaan' melainkan merasuk ke sistem-sistem sosial lain. Struktur dan hirearki kelas juga dapat ditemukan dalam pekerjaan, di mana ada jenis pekerjaan tertentu yang 'derajatnya' lebih tinggi dibandingkan jenis pekerjaan lain. Hal ini menunjukkan bahwa di dalam sistem masyarakat kelas, juga terdapat sistem subkelas yang menyebabkan penindasan berlapis bagi kaum perempuan.

\section{Mitos Tubuh Perempuan: Sensual dan Menggoda}

Mitos tentang tubuh perempuan yang menarik secara seksual, menggoda, dan eksotis telah dibangun selama bertahun-tahun. Produksi dan penyebaran mitos ini melalui media telah mengarah pada pembentukan masyarakat kontemporer di mana perempuan adalah objek hasrat bagi laki-laki. Dalam budaya patriarki, perempuan dilihat sebagai 'tontonan' laki-laki (vanZoonen, 2006). Dalam pertunjukan musik dangdut misalnya, perempuan mengalami objektifikasi ketika tubuh mereka dianggap sebagai 'bahan dekoratif' yang dilapisi dengan pakaian provokatif dan sensual untuk memenuhi kebutuhan audiens laki-laki akan hiburan. Teks media, seperti film dan iklan, secara simultan membentuk mitos tubuh perempuan dengan penggambaran perempuan sebagai simbol seks dan terkadang sebagai 'piala' bagi kemenangan atau kepahlawanan laki-laki. Milestone dan Meyer (2012) menyatakan bahwa perempuan pada umumnya didefinisikan dan direduksi oleh penampilan fisik mereka.

Selain itu, mitos tentang tubuh perempuan juga membentuk pemahaman bahwa perempuan harus menjaga kehormatannya di atas segalanya, artinya mereka harus suci, tidak bersalah secara seksual, pemalu, dan rendah hati agar menjadi feminin sebagaimana yang ditetapkan oleh norma masyarakat
(Milestone \& Meyer, 2012). Di satu sisi, untuk menjadi perempuan yang berbudi lurhur, kesucian dan aseksualitas harus dijaga, akan tetapi di sisi lain, perempuan juga harus menyenangkan laki-laki secara seksual sesuai dengan norma sosial. Kontradiksi ini menggambarkan kontrol laki-laki terhadap perempuan di mana ia harus menyesuaikan sikap dan perilakunya terkait seksualitasnya sesuai dengan kebutuhan dan keputusan laki-laki: kapan perempuan harus menjaga kesuciannya dan kapan perempuan diperbolehkan untuk tampil sensual. Ketika laki-laki memutuskan, perempuan harus patuh dan takut, kemudian bersedia melakukan apapun untuk menyenangkan laki-laki.

Ketika perempuan dimitoskan tidak memiliki kuasa penuh atas seksualitasnya, khususnya saat perempuan dianggap sebagai objek seksual bagi kaum laki-laki, laki-laki justru dianggap berkuasa dan mendominasi secara seksual dalam relasinya dengan perempuan. Mitos dominasi seksual dan praktik seksual 'khas laki-laki' merupakan elemen kunci dalam membentuk budaya masyarakat. Seksualitas adalah topik yang secara ketat dilihat dari perspektif laki-laki dan menguntungkan laki-laki, di mana mereka digambarkan sebagai individu dominan yang bahkan menggunakan kekerasan dalam tindakan seksual mereka, semata-mata untuk mendominasi lawan jenis.

Laki-laki seringkali menggunakan seksualitas untuk menghukum dan mempermalukan perempuan (Irons, 2010). Cara ini relevan dengan penjabaran Walby (2013) tentang struktur patriarki, di mana seksualitas menjadi salah satu elemen penopangnya. Keinginan untuk mendominasi dan mempermalukan perempuan disamarkan sebagai hasrat seksual dan istilah tersebut lah yang ditransmisikan kepada masyarakat. Hal ini semakin mempertegas kebingungan antara seksualitas laki-laki dan kekerasan laki-laki, menghapus hambatan yang terletak di antara kedua tindakan tersebut, menggabungkannya, dan melabelinya sebagai tindakan yang 'tidak bermasalah'.

Struktur patriarki publik beroperasi secara efektif pada perempuan pekerja seni, termasuk perempuan penyanyi dangdut. Patriarki mereduksi makna pekerjaan perempuan pekerja seni dengan mengkonstruksi konotasi negatif dalam persepsi masyarakat tentang profesi tersebut. Salah satu cara yang dilakukan adalah dengan meonjolkan asosiasi perempuan pekerja seni dengan aspek ketubuhan atau seksualitas perempuan dan mengesampingkan aspek kapabilitas dan profesionalitas perempuan dalam menekuni profesi tersebut. Selain itu, patriarki juga beroperasi dalam produksi teks media dengan menciptakan representasi yang menonjolkan perempuan pekerja seks komersial atau perempuan prostitusi sebagai perwakilan dari profesi perempuan pekerja seni. Akibatnya, perempuan yang bekerja di bidang hiburan identik dengan 'jualan tubuh' semata. Hal ini semakin mempersempit pemahaman 
masyarakat tentang ruang lingkup dan makna pekerjaan perempuan pekerja seni yang sebenarnya. Melalui cara-cara tersebut, patriarki berhasil menciptakan kategorisasi dalam benak masyarakat yang memposisikan pekerjaan perempuan pekerja seni sebagai profesi yang sarat stigma, menyimpang, dan merendahkan martabat pekerjanya. Oleh karena itu, perempuan-perempuan yang menggeluti bidang hiburan pada akhirnya dianggap menyimpang, tidak bermartabat, dan sering mendapatkan penilaian negatif atau stigma dari masyarakat.

Masalah seksualitas dan gender harus disoroti karena melalui mitos ini, sistem patriarki jelas digambarkan. Perempuan direduksi menjadi objek hasrat seksual yang melayani kebutuhan laki-laki. Sedangkan seksualitas maskulin mencari kesenangan melalui kekerasan dan kekuasaan. Dengan demikian, mitos seksualitas telah menghapus penghalang antara kesenangan dengan kekerasan dalam relasi laki-laki dan perempuan.

\section{Mitos Feminitas: Perempuan Baik-baik VS Perempuan Tidak Baik}

Masuknya perempuan ke ranah publik mendorong patriarki untuk 'menyesuaikan' bentuk kekerasannya terhadap perempuan. Patriarki publik mempraktikan kekerasan yang bersifat publik dengan menyerang feminitas perempuan. Brownmiller (2013) berpendapat bahwa kekerasan merupakan basis kontrol laki-laki atas perempuan. Kontrol tidak hanya dilakukan pada satu atau dua orang perempuan yang menjadi korban kekerasan, tetapi juga kepada semua perempuan melalui diseminasi 'ketakutan'. Walby (2013) menjelaskan bahwa ideologi patriarki menggunakan kekerasan normatif untuk meneror perempuan. Mekanisme ini dilembagakan untuk melakukan kontrol sosial terhadap kaum perempuan. Salah satu bentuk kekerasan normatif adalah melalui pelabelan dikotomois antara pemberian predikat sebagai perempuan baik-baik (good girl) dan perempuan tidak baik (bad girl).

Dalam masyarakat, istilah perempuan baik-baik dan perempuan tidak baik digunakan untuk mengategorikan perempuan berdasarkan sikap dan perilaku tertentu. Sikap dan perilaku yang dimaksud seringkali mengacu pada feminitas perempuan. Misal yang berkaitan dengan seksualitas: perempuan yang berpakaian seksi termasuk dalam kategori perempuan tidak baik atau ia dianggap sebagai perempuan baikbaik karena pakaiannya tertutup. Ada pula yang berkaitan dengan karakter feminin tertentu seperti perempuan yang tutur katanya halus, perilakunya lemah lembut, pemaaf, dan manis adalah perempuan baik-baik, sedangkan kebalikannya adalah perempuan tidak baik. Kelompok perempuan baik-baik adalah mereka yang mematuhi norma-norma sosial, yang tanpa disadari merupakan hasil konstruksi dari perspektif laki-laki tentang 'perempuan yang pantas'. Sedangkan, perempuan tidak baik adalah mereka yang melanggar norma-norma sosial tersebut. Ketika laki- laki memandang bahwa perempuan tersebut telah melawan kuasa mereka. Maka di saat yang sama masyarakat pun menganggap mereka sebagai 'perempuan yang tidak pantas'.

Dikotomi tersebut merupakan mitos populer dalam masyarakat yang dikonstruksi oleh budaya patriarki. Pelabelan perempuan sebagai perempuan baik-baik tidak dipandang dari perspektif perempuan, melainkan perspektif laki-laki (Simmons, 2014). Laki-laki memandang bahwa perempuan baik-baik adalah perempuan yang melanggengkan peran dan posisi perempuan yang pasif dan tunduk pada aturan patriarki. Oleh karena itu, perempuan yang 'mengamini' mitos feminitas dipuja dengan label perempuan baik-baik, sedangkan perempuan yang melawan kekuasaan laki-laki dianggap menyalahi norma dan dicap sebagai perempuan tidak baik. Seiring dengan meresapnya mitos tersebut dalam kehidupan sosial, muncul lah sikap dan perilaku masyarakat yang membela perempuan baik-baik dan menyalahkan perempuan tidak baik. Hal ini dapat dicermati dalam kasus pelecehan seksual di mana perempuan yang menjadi korban akan didefinisikan terlebih dulu apakah ia perempuan baik-baik atau perempuan tidak baik. Jika ia perempuan baik-baik, maka orang-orang akan mengasihaninya karena "ia baik tetapi masih tertimpa musibah" dan jika ia adalah perempuan tidak baik, maka orang-orang akan menyalahkannya dengan komentar "makanya jangan sering keluar malam sendirian".

Internalisasi mitos feminitas dalam diri perempuan membuatnya merasa bersalah jika ia tidak mengikuti aturan yang berlaku, yaitu menjadi perempuan baik-baik. Di lingkungan sosial, predikat sebagai perempuan tidak baik adalah bentuk penghukuman agar perempuan kembali pada bagaimana dan di mana mereka seharusnya. Dalam kondisi yang paling sulit sekalipun, perempuan diharapkan untuk memenuhi harapan sosial dengan menjadi perempuan baik-baik.

Dalam penelitian ini, peneliti berargumen bahwa kelompok perempuan pekerja seni adalah perempuan kelas dua yang posisinya paling lemah dalam masyarakat. Pertama, ia adalah seorang perempuan yang sejak awal sudah dianggap lebih lemah dari kaum laki-laki. Kedua, ia adalah perempuan pekerja seni yang dianggap lebih rendah dari perempuanperempuan lain karena ia termasuk dalam kategori 'perempuan tidak baik' atau 'perempuan yang tidak pantas' bagi kaum laki-laki. Perempuan pekerja seni menghadapi penindasan berlapis yang membuat posisinya dalam masyarakat semakin rendah dan tidak berdaya. Apapun yang dilakukan atau diucapkan oleh seorang perempuan pekerja seni tidak akan dianggap penting oleh masyarakat patriarki.

Peran sosial berbasis gender yang dikonstruksi laki-laki menghasilkan sekaligus memperkuat relasi kuasa antara laki-laki dan perempuan yang timpang. Kekerasan seksual itu sendiri merupakan masalah 
kekuasaan. Pada awalnya adalah untuk menunjukkan siapa yang memegang kontrol situasi, siapa yang lebih berkuasa, dan penunjukan kekuasan itu akhirnya berakibat pada kekerasan dalam bentuk pelecehan seksual, pemerkosaan, penamparan, dan lain-lain. Dalam praktik kekerasan seksual tercermin ketidaksetaraan hak antara laki-laki dan perempuan. Adanya superioritas laki-laki yang menganggap perlakuan kasar terhadap seksualitas perempuan merupakan hal yang wajar.

Millet (2000) memandang bahwa kekerasan seksual merupakan cara laki-laki 'menghukum' perempuan yang melanggar konstitusi patriarki. Perempuan pekerja seni memenuhi kriteria-kriteria yang dibutuhkan kaum laki-laki untuk melegitimasi penghukuman melalui kekerasan. Pertama, ia adalah seorang perempuan yang akan selalu menjadi objek kekerasan bagi laki-laki. Kedua, ia adalah seorang perempuan yang karena profesinya dianggap sebagai perempuan kelas dua, perempuan tidak baik, dan perempuan yang tidak pantas. Perempuan pekerja seni adalah perempuan dengan martabat paling rendah dan posisi paling lemah sehingga dengan menindasnya laki-laki dapat mengaktualisasikan dan mempertontonkan kekuasaannya dengan gemilang kepada kelompok perempuan lain dan masyarakat secara umum.

Dalam penjabaran tentang tanggapan penyanyi dangdut Via Vallen terhadap pesan mesum yang dikirimkan seorang laki-laki kepadanya diperoleh beberapa temuan menarik. Pertama, perempuan pekerja seni yang menjadi korban dapat menceritakan peristiwa pelecehan seksual yang ia alami secara ekspresif di Instagram stories. Ia menjelaskan pengalaman dan sikapnya terhadap peristiwa tersebut melalui kalimat-kalimat pernyataan yang disertai dengan tipografi, warna, dan gambar tertentu untuk mempertegas makna. Kedua, perempuan pekerja seni korban pelecehan seksual dapat bercerita dan menyatakan sikapnya dengan lebih jelas dan tegas di Instagram stories (unggahan Instagram stories 1) daripada dalam komunikasi antar personal (person-toperson) dengan laki-laki pelaku di halaman percakapan Instagram (unggahan Instagram stories 2).

Ketiga, bagi perempuan pekerja seni, fokus masalah adalah isi pesan yang dikirimkan pelaku. Ia memaknai pesan tersebut sebagai pelecehan seksual yang merendahkan dirinya sehingga ia marah. Keempat, bagi laki-laki pelaku, fokus masalah adalah privasi. Ia mengirimkan pesan tersebut secara personal kepada perempuan pekerja seni, tetapi malah disebarkan kepada publik melalui Instagram stories. Kelima, perbedaan fokus masalah membuat komunikasi antara korban dan pelaku tidak mencapai kesepakatan, tidak tuntas, dan tidak berujung pada solusi atas peristiwa tersebut.

\section{DISKUSI}

Stigma sebagai perempuan kelas dua dan individu paling lemah tidak menyurutkan keberanian perempuan pekerja seni untuk melawan kekuasaan laki-laki. Kasus dalam penelitian ini menunjukkan ada perempuan pekerja seni yang melawan laki-laki yang melecehkannya di media sosial. Perempuan pekerja seni tersebut mengekspresikan perasaan dan sikapnya di media sosial setelah ia menerima pesan mesum dari seorang laki-laki yang tidak dikenal.

Cerita pengalaman pelecehan seksual dari perspektif perempuan korban adalah ekspresi yang 'langka' dalam wacana kekerasan seksual di Indonesia. Terdapat dua kondisi yang melatarbelakangi 'kelangkaan' ekspresi otentik tersebut yaitu karena perempuan korban memilih untuk diam sepenuhnya dan karena adanya pihakpihak tertentu yang berusaha menafsirkan serta menceritakan ulang pengalaman korban.

Kondisi pertama disebabkan oleh dampak pelecehan seksual terhadap diri korban, keluarga, dan masyarakat di sekitar korban. Pelecehan seksual dalam konteks dan bentuk apapun merupakan pengalaman yang sangat melukai dan menyakitkan bagi korban. Perempuan yang mengalami pelecehan seksual akan mengalami trauma yang tidak dapat hilang dalam waktu singkat. Kondisi ini diperparah dengan pandangan masyarakat patriarki yang seringkali menyudutkan dan menyalahkan perempuan sebagai penyebab terjadinya pelecehan seksual. Dampak psikologis dan sosio-kultural terhadap korban pelecehan seksual membuat perempuan lebih sering menyimpan pengalamannya dan enggan menceritakan peristiwa tersebut kepada orang lain. Inilah yang kemudian menghasilkan kesunyian wacana pelecehan seksual di ruang publik.

Sedangkan kondisi kedua berkaitan dengan pihak-pihak di sekeliling korban yang berupaya mengartikulasikan pengalaman korban, salah satunya adalah media massa. Masyarakat dapat mengetahui peristiwa pelecehan seksual yang terjadi tetapi tidak dari perspektif korban, melainkan dari perspektif media. Ketika media massa seperti koran dan televisi membahasakan pengalaman korban, tanpa disadari ideologi patriarki yang mengakar pada organisasi media menampilkan cerita tersebut dari perspektif laki-laki. Hasilnya adalah pemberitaan kasus kekerasan seksual yang cenderung menyalahkan dan menyudutkan perempuan, misalnya dengan memposisikan perempuan sebagai objek seksual yang memicu terjadinya pelecehan.

Terlebih jika korban adalah seorang perempuan pekerja seni, pemberitaan tentang kasus pelecehan seksual tersebut tidak dapat dilepaskan dari stigma dan stereotip masyarakat terhadap sosok perempuan pekerja seni. Pelecehan seksual yang dialami penyanyi dangdut perempuan semakin dianggap 'wajar' dan 'layak' terjadi karena korban dianggap sebagai perempuan kelas dua, perempuan penggoda, dan bukan perempuan baik-baik. Ideologi patriarki 
dalam kinerja media massa pada akhirnya meredam ekspresi perempuan korban dengan menyuguhkan cerita yang tidak ramah korban, di mana korban mengalami reviktimisasi dan pelaku mengalami pewajaran atas tindakannya.

Meskipun diliputi perasaan trauma, dorongan untuk menceritakan peristiwa pelecehan seksual yang mereka alami selalu ada dalam diri perempuan. Hanya saja mengungkapkannya secara langsung kepada pihak lain dalam konteks komunikasi tatap muka atau melalui media massa beresiko menghambat ekspresi korban. Cerita korban akan langsung ditanggapi dengan pandangan dan komentar yang meragukan kesaksian dan menyudutkan posisi mereka sebagai perempuan. Hal ini disebabkan oleh ideologi patriarki yang sudah sangat mengakar dalam masyarakat sehingga perempuan akan selalu dianggap sebagai objek opresi apapun kondisi mereka. Cara lain adalah dengan mediasi, yaitu memanfaatkan media massa agar cerita korban sampai ke publik. Sayangnya, cerita korban yang ditransmisikan kepada masyarakat tidak ditampilkan berdasarkan perspektif korban, melainkan perspektif patriarki dalam melihat peristiwa kekerasan seksual.

Terbenturnya perempuan dengan wacana dominan tentang pelecehan seksual di ruang publik membuat mereka mencari kanal-kanal alternatif untuk menyampaikan pengalaman mereka. Media sosial menjadi salah satu kanal yang dipilih oleh perempuan untuk menyampaikan aspirasi mereka tentang pelecehan seksual yang mereka alami. Berbicara tentang media sosial saat ini, maka kita tidak dapat mengabaikan Instagram. Studi-studi menunjukkan bahwa Instagram banyak digunakan oleh kelompok minoritas untuk menyampaikan aspirasi (Duguay, 2016; Gheytanchi \& Moghadam, 2014; McCafferty, 2011), menyosialisasikan kegiatan (Rassi, 2016; Choi \& Lewallen, 2018; Tufecki \& Wilson, 2012), menggalang dukungan dan kekuatan (Cornet, Hall, Cafaro, \& Brady, 2017; Hwang, Ottenbacher, \& Green, 2010). Kelompok minoritas yang dimaksud meliputi kelompok perempuan kulit hitam, LGBTQ (Lesbian, Gay, Bisexual, Transgender, and Queer), siswa korban pelecehan, orang-orang dengan kepercayaan tertentu, dan lain-lain.

Instagram dinilai mampu meminimalisir hambatan komunikasi langsung atau tatap muka dan komunikasi melalui media massa yang selama ini dikhawatirkan oleh kelompok minoritas dalam berekspresi. Hal ini dikarenakan pengguna memiliki kendali sepenuhnya atas apa yang ia ingin dan tidak ingin bagikan ke publik, bagaimana tampilan atau 'kemasan' unggahan, siapa saja yang bisa melihat atau menyaksikan unggahan, boleh atau tidaknya pengguna lain mengomentari unggahan, dan sebagainya. Singkatnya, jika komunikasi yang ingin diciptakan bersifat retorika satu arah (satu orang berbicara ke banyak orang) dan tidak mementingkan umpan balik, maka Instagram adalah pilihan media sosial yang tepat.
Perempuan pekerja seni korban pelecehan seksual merupakan kelompok minoritas yang ingin menyuarakan pengalamannya kepada masyarakat tanpa terhalangi oleh stigma dan penilaian negatif yang 'menjamur' di ruang publik luring. Kasus dalam penelitian ini menunjukkan bahwa perempuan pekerja seni dapat menceritakan peristiwa pelecehan seksual yang dialaminya secara spontan melalui Instagram stories. Sesaat setelah kejadian, yaitu saat perempuan pekerja seni mendapatkan pesan mesum dari seorang laki-laki, ia dapat langsung mengunggah konten (stories atau posts) tentang pengalamannya. Spontanitas ini jarang terjadi di ruang luring karena korban perlu menghubungi orang terdekat (pasangan, teman, dan keluarga) atau mencari pusat pelaporan (kantor polisi, pusat pengaduan) terlebih dulu pasca kejadian untuk menceritakan atau melaporkan pengalamannya.

Kasus dalam penelitian ini juga menunjukkan bahwa perempuan pekerja seni dapat memperlihatkan bukti pelecehan seksual yang menimpanya melalui cuplikan layar pesan mesum yang ditujukan kepadanya dan halaman percakapan antara dirinya dengan laki-laki pengirim pesan. Hal ini dimungkinkan karena perempuan pekerja seni mengalami pelecehan seksual secara verbal di ruang online, di mana jejak digital peristiwa tersebut tidak dapat dihapus. Dengan menunjukkan kedua bukti tersebut, perempuan pekerja seni telah mengatasi kendala pelaporan di ruang luring yang selama ini memposisikan cerita perempuan korban sebagai kesalahpahaman bahkan kebohongan belaka karena korban tidak dapat menunjukkan bukti pelecehan.

Sebagai figur publik, perempuan pekerja seni memiliki banyak pengikut di Instagram. Jumlah follower yang mencapai angka jutaan akun membuat apa yang diunggah oleh perempuan pekerja seni menjadi dilihat atau didengarkan oleh banyak orang. Dalam kasus ini, perempuan pekerja seni mengunggah Instagram stories tentang peristiwa pelecehan seksual yang ia alami dan membukanya untuk publik (pengikutnya di Instagram). Hal ini jarang terjadi di ruang luring, di mana cerita korban hanya akan didengar oleh beberapa orang yang bersedia mendengarkan. Dalam beberapa kasus di lapangan, justru tidak ada orang yang mau mendengarkan cerita korban karena stigma terhadap perempuan korban pelecehan seksual terus dilestarikan oleh budaya patriarki.

Dalam penelitian ini, dapat dilihat bahwa perempuan pekerja seni yang menjadi korban dapat menceritakan peristiwa pelecehan seksual yang ia alami secara ekspresif di Instagram stories. Ia menjelaskan pengalaman dan sikapnya terhadap peristiwa tersebut melalui kalimat-kalimat pernyataan yang disertai dengan tipografi, warna, dan gambar tertentu untuk mempertegas makna. Ekspresi perempuan pekerja seni yang menjadi korban pelecehan seksual dapat dituangkan dengan lebih bebas dan jelas di ruang publik daring dibanding 
luring, membuat suara mereka berpotensi lebih didengar oleh masyarakat luas. Ekspresi tersebut sekaligus menunjukkan bagaimana perempuan pekerja seni yang mengalami pelecehan seksual, dengan segala stigma dan stereotip yang melekat pada dirinya, menantang wacana kelompok dominan tentang perempuan korban kekerasan seksual di masyarakat.

Jika media sosial menjanjikan kebebasan berekspresi bagi siapapun penggunanya tanpa memandang gender, lalu mengapa perempuan pekerja seni tetap mengalami pembungkaman di media sosial? Kasus yang dianalisis dalam penelitian ini menunjukkan bahwa ekspresi perempuan pekerja seni tentang peristiwa pelecehan seksual yang ia alami pada akhirnya terbentur dengan upaya laki-laki yang ingin membungkam suara mereka. Hal ini terlihat jelas dari kedua Instagram stories yang diunggah perempuan pekerja seni tentang peristiwa pelecehan seksual yang menimpanya. Perempuan pekerja seni menyampaikan pengalamannya secara ekspresif melalui teks kalimat, grafis, dan warna yang menegaskan sikap dan tanggapannya terhadap peristiwa tersebut. Akan tetapi, jika ditelisik lebih lanjut, cuplikan layar halaman percakapan yang ada di unggahan Instagram stories kedua justru menunjukkan kondisi sebaliknya.

Percakapan antara korban dengan pelaku melalui fitur direct message Instagram memperlihatkan kegagalan perempuan pekerja seni mengekspresikan dirinya di hadapan laki-laki yang melecehkannya. Perempuan pekerja seni memulai percakapan ini untuk menanyakan alasan laki-laki tersebut mengiriminya pesan mesum, ia ingin mengonfirmasi pandangannya tentang pesan bernada mesum yang dikirim tanpa konteks yang jelas (secara tiba-tiba dan tanpa kedekatan relasi). Secara implisit, perempuan pekerja seni bermaksud mengonfirmasi secara langsung tindakan yang ia anggap sebagai pelecehan seksual kepada laki-laki pengirim pesan: Apakah yang ia rasakan benar? Apakah laki-laki tersebut memang bermaksud melecehkannya?

Sayangnya, upaya komunikasi tersebut tidak menemui kesepakatan. Pelaku tidak menjawab pertanyaan perempuan pekerja seni, ia tidak membenarkan maupun menyangkal pertanyaan tersebut. Pelaku justru menanyakan hal lain yang membuat perempuan pekerja seni merasa bingung dengan perasaannya dan mempertanyakan sikapnya sendiri. Bagi perempuan pekerja seni, apa yang dilakukan oleh laki-laki tersebut jelas merupakan pelecehan seksual terhadap dirinya, tetapi pelaku seolah menganggap tindakannya tidak bermaksud apa-apa. Pelaku kemudian justru mengalihkan pembicaraan ke hal lain. Inilah yang dijelaskan Kramarae (2000) bahwa cerita-cerita pelecehan seksual merupakan perjuangan perempuan tentang bahasa, yaitu bagaimana perempuan membahasakan pengalamannya kepada pihak lain, dibanding perjuangan perempuan terhadap tindakan seksual itu sendiri.

Apa yang dihadapi perempuan pekerja seni dapat dijelaskan melalui teori kelompok terbungkam atau muted group theory. Kelompok terbungkam adalah kelompok minoritas yang dipaksa menggunakan sistem diskursus tertentu, tetapi memiliki sedikit pengaruh di dalamnya (Foss, Foss, \& Griffin, 2006). Kelompok terbungkam adalah mereka yang tersubordinasi oleh kelompok dominan. Dalam masyarakat patriarki, perempuan adalah kelompok terbungkam. Pembungkaman tidak selalu berarti diam. Pembungkaman dapat menghasilkan keheningan, tetapi arti yang lebih luas adalah "apakah perempuan dapat mengatakan semua yang ingin mereka katakan, di mana dan kapan mereka ingin mengatakannya" (Ardener, 2005).

Dari perspektif muted group, pelecehan seksual terhadap perempuan merupakan masalah komunikasi, khususnya bahasa. Memandang pelecehan seksual sebagai masalah bahasa atau artikulasi menjadi penting karena dapat menjelaskan mengapa perempuan pekerja seni yang menjadi korban pelecehan seksual tidak dapat berekspresi dengan bebas di media sosial dan pada akhirnya tetap bungkam. Media sosial menyediakan ruang ekspresi bagi perempuan korban, di mana mereka dapat menceritakan pengalaman mereka secara otentik dan menyampaikan sikap serta gagasan mereka terhadap tindakan pelecehan seksual. Bahasa menjadi elemen krusial yang dipertukarkan melalui media sosial karena melalui bahasa lah makna ditransmisikan dari pengirim ke penerima pesan dan sebaliknya. Akan tetapi, bahasa juga lah yang menjadi kendaraan bagi ideologi untuk mencapai tujuannya, yaitu mempengaruhi bahkan hingga menghegemoni penggunanya. Dalam penelitian ini, peneliti berargumen bahwa bahasa yang dikonstruksi oleh kaum patriarki lah yang mengakibatkan perempuan korban tetap berujung bungkam di media sosial.

Bahasa adalah "kata-kata, pelafalan, dan metode penggabungan keduanya yang digunakan dan dipahami oleh komunitas" (Halliday, 2004). Spender (2009) menjelaskan bahwa bahasa adalah "sarana yang kita gunakan untuk mengklasifikasikan dan mengatur dunia kita, dan cara kita memanipulasi realitas, di mana di dalam struktur dan penggunaannya kita membawa dunia menjadi kenyataan". Permasalahannya adalah bahasa budaya tertentu tidak melayani semua penuturnya secara setara karena tidak semua pembicara berkontribusi dalam cara yang sama untuk perumusannya (Kramarae, 2000).

Bahasa mencerminkan pandangan tentang dunia. Kelompok dominan dalam masyarakat menciptakan sistem bahasa, mendukung konsepsi mereka tentang dunia, dan menyebutnya sebagai bahasa masyarakat. Sementara pada saat yang sama, ada kelompok lain yang ditundukan dan pengalamannya tidak tercermin dalam bahasa itu (Kramarae, 2000). Laki-laki telah 
menjadi kelompok dominan dalam banyak peradaban di dunia, mereka bertanggung jawab atas penciptaan bahasa dalam peradaban tersebut. Kondisi ini menyebabkan perempuan bungkam karena kata-kata dan norma-norma diformulasikan oleh kelompok dominan (laki-laki) dan digunakan untuk memenuhi kepentingan mereka, sehingga perempuan tidak dapat mengartikulasikan pengalaman mereka dengan mudah atau secara langsung kepada masyarakat yang 'tidak pernah benar-benar menjadi perempuan'.

Teori kelompok terbungkam merupakan kerangka untuk mencari cara atau metode penggunaan bahasa menampilkan gambaran tentang apa yang 'alami' dan 'tidak alami' serta bagaimana perempuan 'seharusnya' (Kramarae, 2000). Konsep 'alami' dan 'tidak alami' sangat penting untuk memahami teori kelompok terbungkam. Secara historis, laki-laki memegang kekuasaan politik atas perempuan sehingga persepsi laki-laki tentang realitas lebih dominan. Persepsi alternatif tentang realitas yang ditawarkan oleh perempuan dianggap abnormal sehingga perempuan harus menyesuaikan diri dengan 'sistem ekspresi laki-laki' (Foss, Foss, \& Griffin, 2006).

Pengalaman perempuan berbeda dengan pengalaman laki-laki karena perempuan memiliki model realitas yang sangat berbeda dari laki-laki. Akan tetapi, pengalaman laki-laki lah yang dianggap mewakili pengalaman masyarakat sedangkan pengalaman perempuan cenderung diabaikan. Dalam masyarakat, wacana laki-laki lebih mudah ditemukan secara langsung daripada wacana perempuan yang bersifat non-verbal, tidak jelas, dan terselubung. Mode ekspresi dalam berbagai masyarakat dihasilkan oleh struktur dominan di dalamnya sehingga jika perempuan ingin didengar dan diperhatikan, ia harus menggunakan mode dominan tersebut (Ardener, 2005).

Pelecehan seksual pada dasarnya merupakan pengalaman perempuan, tetapi perempuan tidak dapat mengartikulasikannya karena mereka tidak memiliki kosakata yang sesuai dengan sistem bahasa kelompok dominan. Pertanyaan yang kemudian muncul adalah: "Bagaimana membahasakan perasaan direndahkan karena suatu ucapan dan atau tindakan yang 'menyerang' seksualitas perempuan? Apa kosakata yang tepat untuk menggambarkan peristiwa tersebut? Bagaimana perempuan menjelaskan kepada laki-laki yang tidak mengalami hal itu?" Laki-laki tidak mengenal istilah pelecehan seksual karena itu bukan pengalamannya, sebagai kelompok dominan mereka tidak merasa dilecehkan atas peristiwa tersebut. Jika perempuan ingin menceritakan pengalaman mereka kepada masyarakat, terlebih dulu mereka harus berhadapan dengan logika dan sistem bahasa laki-laki. Kemudian mereka harus membahasakannya dengan mode ekspresi laki-laki agar pengalamannya dapat dipahami oleh laki-laki.

Masalah inilah yang dihadapi perempuan pekerja seni korban pelecehan seksual. Perempuan pekerja seni tidak memiliki kosakata yang tepat, jelas, dan lugas untuk mengkonfirmasi alasan laki-laki tersebut mengiriminya pesan mesum. Dibandingkan dengan menanyakan secara langsung dan terus terang "mengapa kamu mengirimi saya pesan seperti itu?", perempuan pekerja seni lebih memilih untuk bertanya "apakah kamu mabuk?" kepada laki-laki pengirim pesan. Perempuan pekerja seni kesulitan menggunakan bahasanya sendiri untuk menjelaskan pengalamannya dan akhirnya memilih untuk menyesuaikan bahasanya dengan logika bahasa kelompok dominan.

Ketika ia mengonfirmasi pandangannya kepada pelaku secara langsung, laki-laki tersebut justru mengabaikan pertanyaan itu dan memunculkan permasalahan baru. Masalah yang diajukan oleh lakilaki tersebut justru menyalahkan sikap perempuan pekerja seni yang membagikan cuplikan layar melalui unggahan Instagram stories. Perempuan pekerja seni tidak dapat mengekspresikan pandangannya dalam dominasi wacana maskulin. Ekspresi perempuan pekerja seni dianggap tidak jelas, tidak dimengerti, dan tidak dihiraukan. Hal ini dikarenakan bahasa yang didominasi laki-laki memposisikan perempuan sebagai kelompok yang tidak kompeten dan 'peniru laki-laki yang payah' sehingga berbagai konflik dalam makna bahasa selalu diselesaikan dengan caracara yang menguntungkan kelompok dominan. Siklus resolusi yang tidak seimbang memperkuat posisi dan kekuasaan kelompok dominan dalam masyarakat.

Spender (2009) menyatakan bahwa untuk menjaga kontrol terhadap retorika, kelompok dominan seringkali tidak menyerang isi pesan, tetapi menyerang cara penyampaiannya. Dengan tidak berfokus pada pesan, kelompok dominan tetap dapat menjaga kontrol dan mengesankan bahwa perempuan yang bersalah dalam hal ini dan harus menyesuaikan diri. Inilah yang terjadi ketika perempuan pekerja seni mengekspresikan pandangannya tentang pelecehan seksual yang menimpanya. Bagi perempuan pekerja seni, pesan yang dikirimkan oleh pelaku adalah pesan bernada mesum yang melecehkan dirinya. Sedangkan bagi laki-laki, pesan tersebut adalah pesan pribadi yang dikirimkan kepada seorang perempuan pekerja seni. Hal ini berkaitan dengan mitos ketubuhan yang dikonstruksi patriarki terhadap diri perempuan pekerja seni sehingga pesan yang sarat dengan simbol-simbol sensualitas tesebut dianggap 'layak' untuk dikirimkan karena penerima pesan adalah seorang perempuan pekerja seni. Bagi laki-laki isi pesan tidak bermasalah, permasalahan justru ada pada sikap perempuan pekerja seni yang mengumbar privasi dengan mengunggah cuplikan layar berisi pesan tersebut kepada publik.

Terdapat fokus permasalahan yang berbeda antara korban dan pelaku. Spender (2009) menjelaskan bahwa perempuan secara harafiah diredam dalam dua cara, yaitu dengan memberikan kesempatan terbatas untuk berbicara dan denngan mengintimidasi atau mendiskreditkan perempuan saat 
mereka berbicara. Terlihat jelas bahwa pelaku mengabaikan isi pesan dan kemudian menyerang cara perempuan pekerja seni menyampaikan pesan. Pelaku menyalahkan perempuan pekerja seni yang dengan sengaja mengumbar privasi kepada publik. Melalui cara ini, laki-laki mendiskreditkan ekspresi perempuan, membuat apa yang dirasakan dan diucapkan oleh perempuan terkesan tidak dapat dipercaya, bahkan oleh diri perempuan itu sendiri. Cara ini berhasil membuat korban marah sekaligus merasa bingung sehingga ia memutuskan untuk tidak melanjutkan percakapannya dengan pelaku. Pada akhirnya, korban pun memilih diam.

Cara kelompok dominan membungkam perempuan berjalan dengan mulus ketika perempuan tersebut berprofesi sebagai perempuan pekerja seni. Selama ini, patriarki telah melestarikan stigma-stigma negatif tentang perempuan pekerja seni dalam masyarakat: mereka dikategorikan sebagai 'bukan perempuan baik-baik', perempuan yang tidak 'suci', perempuan tidak bermoral, perempuan kelas dua, perempuan 'rendahan', dan sebagainya. Pertanyaannya, ketika ada perempuan pekerja seni yang mengalami pelecehan seksual dan menceritakan pengalamannya kepada kita, apakah kita lantas percaya dengan cerita mereka? Sebagian besar dari kita akan menanyakan hal yang sama dalam benak masing-masing.

Kasus dalam penelitian ini menunjukkan bahwa ekspresi perempuan pekerja seni yang menjadi korban pelecehan seksual tidak hanya dibungkam oleh lakilaki pelaku, tetapi juga oleh orang-orang yang mendukung pelaku. Perlu ditekankan bahwa sesuai dengan keterangan yang disampaikan oleh perempuan pekerja seni, pelaku adalah seorang pemain sepak bola terkenal di Indonesia. Warganet meyakini bahwa sosok laki-laki tersebut adalah pemain sepak bola asal negara lain yang kemudian dikontrak untuk bergabung dalam klub ternama di Indonesia. Sebagai pemain sepak bola terkenal tentunya laki-laki tersebut memiliki banyak pendukung (supporter) atau penggemar (fans) yang siap menyemangati dan membela idola mereka, bahkan ketika sang idola terindikasi melecehkan seorang perempuan pekerja seni di media sosial.

Ketika perempuan pekerja seni menceritakan pengalamannya di media sosial, berbagai komentar dari warganet bermunculan. Saat perempuan pekerja seni mengunggah post tentang sikap dan pernyataannya sesaat setelah peristiwa pelecehan terjadi, kolom komentar postingan tersebut langsung dibanjiri oleh komentar dari supporter laki-laki tersebut. Berikut adalah beberapa contoh komentar dari warganet yang merupakan supporter klub tempat laki-laki tersebut bergabung.

"Kek gini aja di posting....ap susah nya gak usah di layanin di block aj mba....sama aj ngejatuhin nama orang ini,mba jg pasti ada kekurangan nya...nama nya manusia ad khilaf nya...jgn mentang mentang lg tenar mba...banyak ko artis lain yg dpt DM kaya ginian mereka cuek aja tuh.....parah ni jatuhin nama baik orang...@ viavallen bisa di tuntut Lo mba nanti sama pihak@persijajkt sekaligus di benci the Jak mania...mba kan kerja di Jakarta...emang gk takut ....suporter bola di Indonesia brutal Lo mba"

@ ro.meo2502 (5 Juni 2018), diunduh dari https://www.instagram.com/p/BjnXaviHDv2/

“@viavallen tolong apus kata2 lu yg menyudutkan marko simicc, itu belum tentuu dari dia pribadi, kalo pun iya dia bilang gitu pasti ia hanya bercanda dan tidak seriuss, jgn di besar2kan anda ini artiss jadi pusat perhatian sетиa org. Jgn ganggu fokus simic"

@ rizkyy_mrc (5 Juni 2018), diunduh dari https://www.instagram.com/p/BjnXaviHDv2/

"Hal gitu aja disebarin, mungkin klo itu benar simic blm tentu simic yg kirim, lagian pasti ada juga simic" sebelumnya yg krim, tapi karena simic dikenal jadi yg dipublikasinya jadi ramedahwkqkwkwkw@viavallen"

@ herihernada (4 Juni 2018), diunduh dari https://www.instagram.com/p/BjnXaviHDv2/

Komentar-komentar tersebut cenderung menyudutkan perempuan pekerja seni yang menjadi korban pelecehan seksual dan membela pelaku yang merupakan seorang laki-laki yang berprofesi sebagai pemain sepak bola terkenal. Melalui komentar tersebut terlihat jelas bahwa pelecehan seksual merupakan persoalan relasi kuasa, yaitu bagaimana gender dengan kekuasaan yang lebih besar (dominan) mengopresi gender yang kekuasaannya lebih rendah (submisif). Dalam kasus ini, pelaku adalah seorang laki-laki yang dalam masyarakat patriarkal merupakan gender dominan dan menyandang status sebagai pemain sepak bola dengan basis supporter yang besar. Ketika kasus pelecehan seksual melibatkan sang pemain sebagai pelaku, para supporter akan bersama-sama memberikan dukungan kepada pelaku. Hal ini semakin menguatkan dominasi maskulin dalam wacana pelecehan seksual terhadap perempuan pekerja seni.

Ketimpangan relasi kuasa menjadi semakin besar ketika korban adalah seorang perempuan pekerja seni yang dalam masyarakat patriarkal dianggap sebagai perempuan kelas dua dan pelaku merupakan seorang laki-laki dengan status sosial yang lebih tinggi dan kekuasaan yang lebih besar. Apapun ekspresi yang disampaikan oleh seorang perempuan pekerja seni akan diredam oleh pihak-pihak yang mengidolakan sang pemain. Komentar-komentar negatif yang menyudutkan korban semakin menyurutkan niat perempuan pekerja seni untuk melanjutkan perjuangannya memperoleh keadilan sehingga pada akhirnya ia memilih untuk menutup kasus ini. Kondisi ini menunjukkan bahwa pembungkaman terhadap perempuan pekerja seni dilakukan bukan hanya oleh pelaku, tetapi oleh masyarakat yang 'mengagungkan' dominasi maskulin dalam wacana pelecehan seksual.

Ekspresi penyanyi dangdut yang menjadi korban pelecehan seksual tidak bermakna bagi masyarakat 
Indonesia yang patriarkal. Sejak awal, penyanyi dangdut sudah diposisikan sebagai perempuan kelas dua dan perempuan paling lemah dalam struktur sosial. Berbagai atribut seksualitas dilekatkan kepadanya sehingga mereka dipandang sebagai individu yang tidak bermoral dan tidak bermartabat. Perempuan pekerja seni merupakan 'sasaran empuk' penindasan laki-laki yang diwujudkan dalam bentuk pelecehan seksual. Ketika penyanyi dangdut mengekspresikan pengalaman pelecehan seksual yang menimpanya, laki-laki memaknainya sebagai perlawanan terhadap kekuasaan kelompok dominan. Patriarki kemudian bekerja secara sistematis untuk membungkam perempuan dan mengembalikan perempuan pekerja seni ke 'tempat semestinya' ia berada.

Siapa yang akan mempercayai pengalaman seorang penyanyi dangdut? Meskipun pengalaman tersebut berharga untuk dibagikan, tetapi pengalaman seorang penyanyi dangdut adalah pengalaman eksklusif terkait dengan profesinya. Masyarakat memandang pelecehan seksual yang menimpa penyanyi dangdut adalah hal yang wajar karena pekerjaan mereka sendiri lah yang 'mengarahkan' mereka sehingga mengalami pengalaman tersebut. Ketika penyanyi dangdut mencoba mengartikulasikan pengalaman mereka, masyarakat patriarki 'membentengi' diri mereka dengan stigma-stigma dan persepsi negatif. Pada akhirnya, kondisi yang terjadi sesuai dengan pernyataan Ardener (2005) bahwa perempuan memang berbicara, tetapi kata-kata mereka jatuh pada telinga yang tuli, seiring berjalannya waktu, perempuan cenderung berhenti untuk mengemukakan pendapat dan bahkan mereka mulai berhenti untuk memikirkannya.

Munculnya keraguan terhadap ekspresi perempuan pekerja seni yang menjadi korban pelecehan seksual adalah bukti keberhasilan ideologi patriarki dalam mengkonstruksi persepsi masyarakat. Sedikit demi sedikit dan secara perlahan-lahan patriarki menanamkan penilaian negatif tentang sosok penyanyi dangdut dalam persepsi masyarakat dengan berbagai cara, termasuk melibatkan representasi media di dalamnya. Pada momen yang tepat, misal pada saat laki-laki menindas penyanyi dangdut dan terjadi perlawanan, patriarki cukup memantik ingatan masyarakat tentang penyanyi dangdut. Hal yang kemudian terjadi adalah ekspresi penyanyi dangdut tidak hanya berhadapan dengan pelaku penindasan, melainkan juga masyarakat patriarki secara umum.

Apa yang dilakukan oleh kelompok dominan mempengaruhi langkah perempuan dalam menghadapi masalah. Upaya-upaya ini beroperasi di alam bawah sadar perempuan dan kelompok dominan seringkali tidak mau mengakuinya. Hasilnya jelas perempuan dibungkam dalam berbagai cara, banyak dari cara-cara tersebut yang mematikan ekspresi perempuan secara halus. Inilah yang terjadi pada kasus dalam penelitian ini, di mana ekspresi perempuan pekerja seni tidak hanya dibungkam oleh pelaku tetapi juga oleh masyarakat di ranah daring (warganet) dan luring. Hasilnya, perempuan pekerja seni tidak lagi mengekspresikan dirinya terkait peristiwa pelecehan yang menimpanya di ranah online dan juga tidak melanjutkan kasusnya di ruang offline. Peristiwa pelecehan seksual terhadap perempuan pekerja seni tidak lagi dibahas maupun diperjuangkan, menguap begitu saja layaknya kebanyakan kasuskasus pelecehan seksual yang dialami perempuan di Indonesia. Sekali lagi, perempuan korban pelecehan seksual dibungkam oleh kuasa kelompok dominan.

Manifestasi relasi kuasa terdapat dalam bahasa (Wood, 2005). Relasi kuasa berkaitan langsung dengan gender khususnya dalam hal akses, distribusi, dan penggunaan sumber daya yang didistribusikan secara tidak merata antara laki-laki dan perempuan (Sultana, 2011). Bias maskulin dalam bahasa tidak terbatas pada arti kata saja, melainkan juga dalam struktur bahasa yang mendukung 'laki-laki sebagai norma'. Kosakata Bahasa Inggris misalnya, laki-laki adalah pemberi nama (namer) sedangkan perempuan adalah yang diberi nama (named). Kebanyakan kata yang digunakan untuk melabeli perempuan, tidak peduli apapun makna denotatifnya, akan memperoleh konotasi yang merendahkan.

Spender (2009) menegaskan bahwa bahasa gender adalah salah satu cara laki-laki mengintimidasi dan meremehkan perempuan ke dalam keheningan. Ketidakadilan ini menciptakan apa yang digambarkan oleh Spender sebagai "keheningan yang keras". Masalah terletak pada kenyataan bahwa perempuan tidak bisa kembali ke masa lalu dan menciptakan bahasa baru, pun tidak bisa menambahkan kosakata 'perempuan' ke dalam bahasa ketika struktur dan sistem yang ada dibangun sesuai dengan kriteria patriarkal.

Wood (2008) menjelaskan manfaat memegang kendali untuk memberi nama sesuatu adalah sebagai berikut "Mereka yang menamai dunia memiliki keistimewaan (priviledge) untuk menonjolkan pengalaman mereka dan menentukan apa saja yang penting bagi mereka, sekaligus menghapus pengalaman yang tidak mereka ketahui atau anggap penting untuk diberi nama. Hal ini terjadi ketika terminologi "pelecehan seksual" dan "kekerasan seksual" dicetuskan pada tahun 1970. Mengapa harus menunggu hingga tahun 1970-an? Apakah tindakantindakan yang mengancam seksualitas perempuan tidak pernah terjadi hingga tahun 1970 ? Tidak, pada dasarnya pelecehan seksual adalah pengalaman perempuan dan laki-laki tidak memiliki cukup alasan untuk menamai hal tersebut karena mereka tidak pernah mengalaminya. Kondisi ini membuat perempuan kesulitan untuk menjelaskan situasinya, seperti apa pelecehan seksual itu sendiri.

Selama para perempuan mencoba untuk mengkomunikasikan pengalaman mereka dalam suatu sistem bahasa yang tidak dirancang untuk digunakan, mereka tidak akan sepenuhnya dapat mengartikulasikan apa artinya menjadi seorang 
perempuan. Perempuan yang mencoba mengubah kondisi ini dipandang sebagai perempuan egois yang ingin meninggalkan peran perempuan tradisional demi dapat memasuki ranah laki-laki.

Para feminis menyimpulkan bahwa pada setiap kemenangan yang diraih perempuan selalu ada serangan balik patriarki di area yang lain. Ketika perempuan memasuki ruang publik offline, patriarki beroperasi dalam wujudnya yang kasat mata (physical), salah satunya dengan melakukan kekerasan yang menyerang fisik maupun seksualitas perempuan. Cara ini berhasil mengurung perempuan dalam kekhawatiran ketika beraktivitas di ruang publik tanpa menghiraukan 'norma sosial' seperti berjalan sendirian, tidak mengenakan pakaian tertututup, pulang larut malam, dan sebagainya. Ketika perempuan menjadi korban pelecehan seksual, mereka tidak dapat menceritakan pengalaman mereka untuk memperoleh keadilan karena ekspresi mereka dibungkam oleh pihak-pihak yang melegitimasi dominasi maskulin di masyarakat.

Perempuan 'menang' ketika ia dapat menceritakan pengalaman pelecehan seksual yang menimpanya di media sosial kapanpun, dimanapun, dan dengan cara apapun ia ingin menyampaikannya. Akan tetapi, patriarki merupakan sebuah sistem yang dinamis di mana laki-laki biasanya menyerahkan sebuah aktivitas hanya ketika mereka sudah tidak ingin mengerjakanya lagi. Jika perempuan memang menggapai sebuah kemenangan, maka kekuatankekuatan patriarki akan berkumpul lagi dan meraih kembali kontrol atas perempuan melalui cara yang berbeda, salah satunya dengan menggunakan bahasa yang sejak awal tidak diciptakan untuk perempuan.

Patriarki di ranah online beroperasi melalui bahasa yang tanpa disadari telah mengopresi perempuan. Kasus dalam penelitian ini menunjukkan bagaimana patriarki sebagai ideologi dominan diaktualisasikan dalam bahasa-bahasa yang menyudutkan dan meredam ekspresi perempuan pekerja seni yang mengekspresikan pengalaman pelecehan seksualnya di media sosial.

Bahasa kelompok dominan mengunci perempuan dalam kebingungan dan kekhawatiran untuk menyampaikannya bahasanya sendiri di media sosial. Perempuan perlu berpikir ulang untuk menyatakan ekspresinya di ruang publik online dan ketika mereka berbicara di media sosial, ekspresi mereka akan langsung diredam oleh kelompok dominan. Pada akhirnya, mereka memilih untuk tidak berbicara sama sekali daripada harus berhadapan dengan komentarkomentar warganet yang 'ganas'.

Menghadapi upaya-upaya pembungkaman tersebut, Spender (2009) menjelaskan bahwa "Jika dan ketika banyak orang tidak lagi memberikan konsensus pada mitos superioritas laki-laki, jika dan ketika mereka tidak lagi bertindak menyetujui bahwa superioritas tersebut tidak tertandingi, maka daripada menerima apa adanya, kekuasaan tersebut perlu dilawan atau diubah." Apa yang dapat kita pelajari dari kasus perempuan pekerja seni yang mengekspresikan pelecehan seksual yang menimpanya adalah perempuan sebaiknya tetap berbicara secara otentik dan aktif di ruang publik, baik secara langsung maupun melalui media sosial.

Patriarki akan selalu menantang upaya-upaya perempuan yang berpotensi mengancam tatanan dominasinya di masyarakat. Dengan demikian, usahausaha pembungkaman ekspresi perempuan akan selalu ada dimanapun, kapanpun, dan dengan cara apapun perempuan berbicara. Perempuan pekerja seni sebaiknya tidak lagi berfokus pada stigma dan stereotip yang dapat menghalangi ekspresi mereka. Norma sosial, meskipun memiliki kekuatan, pada hakikatnya akan dan dapat berubah. Riset di bidang psikologi menunjukkan bahwa anggota kelompok mengubah persepsinya dengan sangat cepat ketika mereka percaya bahwa anggota lain juga telah mengubah keyakinannya (Crane, 2005). Oleh karena itu, yang dibutuhkan adalah keberanian untuk berbicara apa adanya dan berargumen di ruang publik ketika suara perempuan dipertanyakan.

Kasus pelecehan seksual di ranah online belum lama kembali terjadi. Kali ini korbannya adalah Zoya Amirin, seorang akademisi dan seksolog yang aktif menjadi narasumber di berbagai media. Pada 3 Oktober 2020, Zoya Amirin mengunggah postingan Instagram di akun pribadinya (@zoyaamirin) yang menceritakan peristiwa pelecehan yang ia alami dan secara terang-terangan membuka identitas akun si pelaku.

Pelaku beberapa kali menulis komentar yang melecehkan pada unggahan Zoya Amirin. Dalam kasus Zoya Amirin, dapat kita cermati bagaimana perempuan yang bukan pekerja seni atau tidak berkarir di dunia hiburan pun rentan mengalami pelecehan seksual di ranah online. Dalam struktur patriarki, sosok Zoya Amirin yang berprofesi sebagai seksolog akan selalu dilekatkan dengan mitos kebertubuhan. Hasilnya adalah imej Zoya Amirin sebagai perempuan yang sensual dan menggoda. Imej ini tampil dominan dan akhirnya malah mendevaluasi pemikiran dan kepakaran profesional seorang Zoya Amirin.

Berbeda dengan pengalaman Via Vallen, unggahan Zoya Amirin mengundang banyak reaksi positif warganet. Lewat kolom komentar, warganet mengapresiasi keberanian Zoya Amirin untuk membicarakan pengalamannya dan mendukung keputusannya membuka identitas pelaku. Banyak apresiasi dan dukungan dari para perempuan yang turut menyampaikan sikapnya terhadap pelecehan seksual di media sosial.

Dari respon warganet, khususnya para perempuan, kita bisa melihat bahwa tidaklah penting mengubah persepsi setiap laki-laki satu per satu. Perempuan lebih baik mendorong perubahan dengan senantiasa menggunakan cara mereka sendiri dalam berkomunikasi. Di era digital ini, perubahan masif dapat dilakukan dengan memanfaatkan media sosial. 
Instagram misalnya, digunakan oleh ribuan orang untuk merealisasikan gerakan tertentu dan mengajak banyak orang untuk berpartisipasi di dalamnya (seperti gerakan \#MeToo, \#MulaiBicara, \#GerakBersama, dan lain-lain). Perempuan pekerja seni dapat mendorong terciptanya gerakan sosial yang menjadi kanal penyampaian aspirasi terhadap pelecehan seksual yang tidak hanya menjangkau sesama perempuan, tetapi juga masyarakat Indonesia secara lebih luas.

Dengan adanya media sosial, perempuan pekerja seni dapat menyusun strategi komunikasi yang efektif untuk menyampaikan pesan perlawanannya terhadap pelecehan seksual kepada masyarakat luas. Mereka dapat mengkonstruksi dan mendistribusikan pesan perlawanan secara lebih matang serta dapat memberikan umpan balik berupa argumen-argumen edukatif yang mampu menandingi komentarkomentar negatif yang sarat dengan nilai-nilai patriarki. Dengan keberanian berekspresi, pada akhirnya perempuan akan sampai pada titik di mana kita akan melihat konsen perempuan tentang kekerasan seksual dapat diterima dengan baik tanpa memandang siapa dan apa profesi perempuan tersebut.

\section{KESIMPULAN}

Berdasarkan penjabaran hasil penelitian dan diskusi, maka kesimpulan penelitian ini adalah pembungkaman ekspresi perempuan pekerja seni terjadi ketika ia berkomunikasi langsung dengan pelaku untuk mengonfirmasi pandangannya tentang peristiwa pelecehan tersebut. Pembungkaman dilakukan oleh kelompok dominan dengan mengalihkan isu, dari pesan mesum yang melecehkan perempuan menjadi pelanggaran privasi, yang kemudian mengarah pada upaya menyalahkan dan mendiskreditkan perempuan pekerja seni yang menjadi korban.

Kondisi ini disebabkan oleh ideologi patriarki yang mengakar di masyarakat beroperasi secara sistematis untuk membungkam ekspresi perempuan pekerja seni yang menjadi korban pelecehan seksual. Pertama dengan mengkonstruksi posisi perempuan pekerja seni dalam masyarakat, kedua dengan menyuburkan stigma dan penilaian negatif tentang sosok perempuan pekerja seni, ketiga dengan menindas mereka melalui pelecehan seksual dan menjadikan pengalaman ini eksklusif bagi kelompok mereka, dan keempat 'berpura-pura menjadi tuli' ketika perempuan pekerja seni menyuarakan aspirasi mereka tentang pelecehan seksual. Akhirnya, ketidakmampuan perempuan pekerja seni mengartikulasikan pengalaman pelecehan seksual di hadapan kelompok dominan membuat dirinya merasa bingung, mempertanyakan sikapnya, dan akhirnya memilih untuk tidak melanjutkan pembahasan kasus ini.

\section{REFERENSI}

Ardener, S. (2005). Perceiving Women. Sydney: Halsted Press.

Arivia, G. (2006). Feminisme: Sebuah Kata Hati. Jakarta: Penerbit Buku Kompas.

Barthes, R. (2007). S/Z: An Essay. New York: Farrar, Straus, and Giroux.

Brownmiller, S. (2013). Against Our Will: Men, Women, and Rape. New York City: Open Road Media.

Chandler, D. (2006). Semiotics: The Basics. London: Routledge.

Chatterjee, R. (2018, Februari 21). A New Survey Finds 81 Percent of Women Have Experienced Sexual Harassment. Dipetik September 11, 2018, dari National Public Radio Website: https://www.npr.org/sections/thetwoway/2018/02/21/587671849/a-new-survey-findseighty-percent-of-women-have-experienced-sexualharassment

Chodorow, N. J. (2012). Individualizing Gender and Sexuality: Theory and Practice. London: Routledge.

Choi, G. Y., \& Lewallen, J. (2018). "Say Instagram, Kids!": Examining Sharenting and Children's Digital Representations on Instagram. Howard Journal of Communications 29(2), 144-167.

Cornet, V. P., Hall, N. K., Cafaro, F., \& Brady, E. (2017). How Image-Based Social Media Websites Support Social Movements. Research Gate Conference Paper, $1-8$.

Crane, T. (2005). The Problem of Perception. Nottingham: Stanford University.

Duguay, S. (2016). Lesbian, Gay, Bisexual, Trans, and Queer Visibility Through Selfies: Comparing Platform Mediators Across Ruby Rose's Instagram and Vine Presence. Social Media + Society (April-June), 1-12.

Foss, K. A., Foss, S. K., \& Griffin, C. L. (2006). Feminist Rethorical Theories. London: Waveland Pr Inc.

Gash, A., \& Harding, R. (2018). \#MeToo? Legal Discourse and Everyday Responses to Sexual Violence. Laws $7(2), 21-30$

Gheytanchi, E., \& Moghadam, V. N. (2014). Women, Social Protests, and The New Media Activism in The Middle East and North Africa. International Review of Modern Sociology 40(1), 1-26.

Halliday, M. A. (2014). Introduction to Functional Grammar (4th Edition). London: Edward Arnold.

Hwang, K. O., Ottenbacher, A. J., \& Green, A. P. (2010). Social support in an internet weight loss community. International Journal of Medical Information 79(1), 513.

Inter Press Service. (2018, February 1). Sexual Harassment: At Least 2 Billion Women. Diambil kembali dari Inter Press Service Website: Global Issues: http://www.globalissues.org/news/2018/02/01/23899

Irons, G. (2010). Gender, Language, and Myth (Digital Version). Toronto: University of Toronto Press.

Komnas Perempuan. (2017, September 12). Kekerasan Seksual (Booklet). Diambil kembali dari Komnas Perempuan Website: https://www.komnasperempuan.go.id/read-newskekerasan-seksual-booklet

Kramarae, C. (2000). Routledge International Encyclopedia of Women: Global Women's Issues and Knowledge. London: Routledge.

McCafferty, D. (2011). Activism Vs. Slacktivism. Communication of the ACM, 12-15. 
Milestone, K., \& Meyer, A. (2012). Gender and Popular Culture. New York: Polity Press.

Millet, K. (2000). Sexual Politics. Illinois: University of Illinois Press.

Rassi, N. (2016). Empowerment, Control \& The Female Body: Is Instagram a Platform for Change? Ottawa: University of Ottawa.

Sonia, U. F. (2016, Mei 19). Ketika media negaramu tak ramah perempuan. Dipetik Oktober 8, 2018, dari Medium Website: https://medium.com/@ursulaflorene/ketika-medianegaramu-tak-ramah-perempuan-a1c8c1c8f5a1

Spender, D. (2009). Man made language (Digital Version). Boston: Routledge \& Kegan Paul, Ltd.

Sultana, A. (2011). Patriarchy and Womens Subordination: A Theoretical Analysis. Arts Faculty Journal 4, 1-18.
Tufecki, Z., \& Wilson, C. (2012). Social media and the decision to participate in political protest: Observations from Tahir square. Journal of Communication 62(2), 363-379.

vanZoonen, L. (2006). Feminist Media Studies. London: SAGE Publications.

Walby, S. (2013). The Future of Feminism. Boston: Polity Press.

Wood, J. T. (2005). Gendered Lives: Communication, Gender and Culture. Belmont: Wadsworth-Thompson Learning.

Wood, J. T. (2008). Communication in Our Lives. Belmont: Cengage Learning.

World Health Organization. (2017, November 29). Violence against women. Diambil kembali dari World Health Organization Website: http://www.who.int/en/newsroom/fact-sheets/detail/violence-against-women 